\title{
The importance of relational values in river management: understanding enablers and barriers for effective participation
}

\author{
Simon A. Mould ${ }^{1}$, Kirstie A. Fryirs ${ }^{1}$ and Richard Howitt ${ }^{1}$
}

\begin{abstract}
Participation by local communities is a key requirement of many environmental management policies globally. Understanding what enables or prevents landholders' participation in environmental management is a fundamental requirement for strategies aiming to utilize this often-voluntary resource base. This research applies the emerging concept of relational values to a river management case study in order to better understand why landholders choose to participate in river management and how river management programs can better respond to landholders' values. We develop a conceptual model to represent the dynamics of participation, identifying "enablers" and "barriers" to participation. We find that relational values, such as relationships between people and environment, motivate participation (or nonparticipation) in river management. Many of the enablers that translate motivating values into participatory actions are also relational in nature. Examples of relational enablers include supportive social networks and investment in relationships by river management practitioners. These findings form the basis for recommendations to help practitioners recognize relational values and prioritize enabling relationships as core activities. Understanding and working with relational values can generate possibilities for improved participation in pursuit of sustainable socio-environmental systems.
\end{abstract}

Key Words: environmental management; participation; relational values; river rehabilitation

\section{INTRODUCTION}

Participation is a key requirement for many environmental programs, recognizing inextricable links between social and environmental processes and actors in the pursuit of sustainable socio-environmental systems. This is recognized globally; for example, as prescribed in the European Water Framework Directive (WFD) and United Nations Commission on Europe's Aarhus Convention (Horangic et al. 2016, Hassenforder et al. 2019). However, all modes of participation are not equal (Arnstein 1969, Head 2007, Reed 2008, Maynard 2013, Euler and Heldt 2018) and characteristics that make one mode of participation successful in one social setting may be unavailable, inappropriate, or ineffective for another (Reed 2008, Mehring et al. 2018, Grassini 2019, Hassenforder et al. 2019). Thus, participatory frameworks must be responsive and adaptive to the social and physical settings in which they are developed and applied (Brierley et al. 2006, Pahl-Wostl et al. 2011, Maynard 2013).

Developing appropriate participatory frameworks, and fostering engagement within those frameworks, requires understanding of how and why people choose to participate. In river management, many participatory frameworks rely on volunteering at a community level, often supported by financial incentives for participation. This is particularly relevant in rural landscapes, where private landholders often have responsibility for managing the environmental condition of the instream, riparian, and floodplain zones of rivers (e.g., Carr 2002, Fryirs et al. 2008, Gregory et al. 2011, Moore et al. 2018). Beyond financial incentives, previous studies have sought to understand the values, beliefs, and attitudes underpinning behaviors, particularly those motivating voluntary participation. For example, Gooch (2003) focused on the role of an "ecological identity" in a dynamic sense of place, which was an important motivator for voluntary participation. Other studies have identified associations between landholder knowledge and level of participation (e.g., Curtis and
Robertson 2003) and find that social norms have an important influence on landholders' environmental behaviors in the long term (Moore et al. 2018).

In many studies on participation, influential values that motivate participation are defined in instrumental (use-based) or intrinsic (inherent) value terms (e.g., Curtis and Robertson 2003, Mendham et al. 2007, Larson and Lach 2008, Seymour et al. 2011, Urgenson et al. 2013, Moore et al. 2018). However, landholders are also motivated to participate by values concerning actual, or desired, relationships with people and with place (Gooch 2003, Measham and Barnett 2008). These values do not fit neatly into instrumental or intrinsic concepts of value; rather, they make up a third category of environmental values called relational values. Relational values are "preferences, principles, virtues based on meaning-saturated relationships" (Chan et al. 2018:A3) and in particular, human-nature relationships. Relational values are concerned with how meaning is made through diverse relationships and are necessarily place-based (Turnhout et al. 2013, Chan et al. 2016, Tadaki et al. 2017).

Relational values have been linked to environmental practices, for example, relationships maintained through performance of ethical roles and stewardship (Turnhout et al. 2013, Tadaki et al. 2017). In this vein, the relational values concept has been used to understand participation in environmental programs and practice. In the context of participation, the concept has been particularly valuable for identifying value conflicts, where friction between locally held relational values and the values embedded in conservation initiatives limit participation in those initiatives (Allen et al. 2018, Chapman et al. 2019). Recent research has also highlighted the motivating power of relational values for supporting the adoption of sustainable agricultural practices (Jones and Tobin 2018). Research in relational values offers opportunities to understand the dynamics of participation in environmental management beyond instrumental and intrinsic 
concepts of value, engendering possibilities for development of participatory practices and programs that are more sensitive to, and appropriate for, the communities and places they aim to engage (Tadaki et al. 2017, Bremer et al. 2018).

In this paper, we investigate the role of relational environmental values in influencing participation in river management by rural landholders and the outcomes of that participation, socially and personally, as expressed by landholders. Interview responses are used to identify factors that interact at interpersonal and community scales to help translate landholders' relational values into direct participation in river management. We use these insights to discuss how programs could/should take better account of the relational factors driving, enabling, and limiting effective participation in river management initiatives, in the pursuit of sustainable socio-environmental systems.

\section{METHODS}

This research uses a case study in the Macdonald Valley, NSW, Australia to investigate factors influencing participation in river rehabilitation projects. The qualitative methodological approach recognized that data concerning relationships and meaning are often not accessible when traditional "sampling" approaches are used, and instead, focused on building relationships with landholders over time as a basis for an ongoing, inductive analysis (c.f. Brandenburg and Carroll 1995). Semistructured interviews were undertaken with 15 respondents (seven female and eight male), comprising 14 resident landholders and one natural resource management practitioner (nonresident; Table 1). Nine of the landholders were active and intentional participants in river rehabilitation activities and 12 owned property with river frontage at the time of writing. Interviewees were recruited initially via existing contacts, who had assisted with previous geomorphological research on the Macdonald River (see Mould and Fryirs 2018), and via an advertisement in a local community newsletter. Relationships with some respondents were established in previous years, building on longstanding hosting of annual undergraduate field trips from the authors' university. This familiarity with the university and some of its researchers eased the process of recruiting initial respondents. Additional interviewees were recruited upon recommendation from existing interviewees until no new names were suggested and new themes were no longer emerging. The Macdonald Valley community is small and well connected beyond river management networks, and the voluntary basis for recruitment inevitably focused the research on local people who were already interested and engaged. However, the recruitment methods meant that many of the key stakeholders active in local river rehabilitation chose to contribute to the research.

Interviewees were asked about their connection to the valley and river (length of time living there, reasons for arriving or remaining, general experiences in community), their level and type of participation in river rehabilitation activities, and their hopes for how the river might be in the future. A guide was developed to structure interviews (Appendix 1), but was sufficiently flexible to explore additional themes raised in conversation. Interviews were between one and two hours duration, took place in respondents' homes, and often included short walks on the respondents' properties, where respondents wished to show the researcher certain features or places. Respondents were given the option to be interviewed individually or in pairs if they were part of a family unit, because some felt more comfortable speaking with a participating family member.

Analysis of the research data followed a grounded theory approach, where iterative analysis and coding throughout the research guided development of categories, which were related and compared to build a conceptual model of the relationships in this case (Corbin and Strauss 1990). Ongoing engagement prior to and following interviews, and verification of data with respondents (c.f. Baxter and Eyles 1997), helped to ensure that researchers maintained themselves as an informed audience for the experiences and testimony of respondents. Qualitative analysis was supported by NVivo software. We initially aimed to fully understand the experiences, activities, and motivations of each individual respondent. Following this, comparisons were drawn between individuals' experiences, activities, and motivations in order to build a picture of the broader social and relational factors influencing participation in this community. Codes were developed from key themes corresponding to the research aims, including motivating values, actions, outcomes, enablers, barriers (Table 2), and further interpretive codes, e.g. under categories of relationships or values, were developed through an iterative process of familiarization and reflection. This research was granted ethical approval by the Macquarie University Human Research Ethics Committee (Ref. 5201700048).

\section{REGIONAL SETTING}

The Macdonald River Valley is in the Hawkesbury River catchment of New South Wales (NSW; Fig. 1). The population of approximately 560 is concentrated in the town of St Albans and in the Lower Macdonald locality. Following colonization by Europeans, the valley was divided into grants and allocated to free settlers and ex-convicts, whose occupation largely displaced the Darkinjung Indigenous people from their land. Some of the early families who were amongst the first to be granted land by the NSW Governor are still represented in the Macdonald Valley. A sequence of five floods between 1949 and 1955 caused significant channel widening via bank erosion and formation of an in-channel sand slug. Subsequent floods in the late 1970s increased in-channel sedimentation, resulting in further loss of geomorphic complexity (Henry 1977, Erskine and Melville 1983, Erskine 1986, Rustomji 2008). Since these floods, the river is showing signs of geomorphic recovery (see Rustomji 2008, Mould and Fryirs 2018).

Community-led river rehabilitation efforts, supported by local government and state government agencies, are contributing to river recovery (Fig. 2). Local participation in river management is primarily via voluntary, incentivized passive rehabilitation works on private land and voluntary "bushcare" bush regeneration on public land. Incentive schemes provided by NSW Local Land Services (LLS, formerly Catchment Management Authority) typically support landholders to undertake passive rehabilitation work. Participating landowners must match LLS's contribution either financially or with in-kind labor and negotiate this through development of a property management plan. Participation is voluntary, so strategic coordination of rehabilitation at the catchment scale, undertaken by LLS, requires understanding, and management, of relationships with landholders. 
Table 1. Respondents in research, assigned random numbers.

\begin{tabular}{|c|c|c|c|c|c|}
\hline $\begin{array}{l}\text { Respondent } \\
\text { Number }\end{array}$ & $\begin{array}{c}\text { Age bracket } \\
(\mathrm{yrs})\end{array}$ & $\begin{array}{c}\text { Gender } \\
\text { (female/ male) }\end{array}$ & Primary land use & $\begin{array}{l}\text { Time spent living in } \\
\text { valley (yrs) }\end{array}$ & $\begin{array}{c}\text { River frontage on } \\
\text { property? }\end{array}$ \\
\hline 1 & $50-59$ & $\mathrm{~F}$ & Hobby farm grazing & $10-20$ & Yes \\
\hline 2 & $50-59$ & M & Hobby farm grazing & $5-10$ & Yes \\
\hline 3 & $60-69$ & $\mathrm{M}$ & Lifestyle & $30+$ & Yes \\
\hline 4 & $50-59$ & $\mathrm{M}$ & Hobby farm grazing & $10-20$ & Yes \\
\hline 5 & $50-59$ & $\mathrm{~F}$ & Hobby farm grazing & $5-10$ & Yes \\
\hline 6 & $60-69$ & $\mathrm{~F}$ & Lifestyle & $30+$ & Yes \\
\hline 7 & $70-79$ & M & Lifestyle & $30+$ & Yes \\
\hline 8 & $40-49$ & M & Grazing & $30+$ & Yes \\
\hline 9 & $70-79$ & $\mathrm{~F}$ & Lifestyle & $30+$ & Yes \\
\hline 10 & $50-59$ & $\mathrm{~F}$ & Lifestyle & $5-10$ & No \\
\hline 11 & $50-59$ & M & Lifestyle & $5-10$ & No \\
\hline 12 & $70-79$ & $\mathrm{~F}$ & Lifestyle & $30+$ & Yes \\
\hline 13 & $80-89$ & M & Grazing & $30+$ & Yes \\
\hline 14 & $70-79$ & M & Lifestyle, weekender & $10-20$ & Yes \\
\hline 15 & Not specified & $\mathrm{F}$ & $\begin{array}{l}\text { Natural resource management } \\
\text { practitioner }\end{array}$ & N/A & Nonresident \\
\hline
\end{tabular}

Table 2. Definitions for key terms used in this paper.

\begin{tabular}{|c|c|}
\hline Key term & Definition \\
\hline $\begin{array}{l}\text { Motivating } \\
\text { values }\end{array}$ & $\begin{array}{l}\text { Values inferred from respondents' articulation of } \\
\text { reasons for participating in river rehabilitation. These } \\
\text { values motivate participants to become involved. } \\
\text { Motivating values may or may not be relational. }\end{array}$ \\
\hline Actions & $\begin{array}{l}\text { The activities through which people participate in river } \\
\text { rehabilitation, including directly, e.g., planting trees, } \\
\text { and indirectly, e.g., influencing another person's } \\
\text { thoughts or actions in relation to river rehabilitation. }\end{array}$ \\
\hline Outcomes & $\begin{array}{l}\text { The results of participation in river rehabilitation. } \\
\text { Includes social outcomes (results for individuals and } \\
\text { community, focused on in this paper) and } \\
\text { environmental outcomes (results for physical and } \\
\text { ecological environment, not focused on in this paper). }\end{array}$ \\
\hline Enablers & $\begin{array}{l}\text { Factors that assist in translating motivating values held } \\
\text { by individuals into action (practices) in river } \\
\text { rehabilitation. }\end{array}$ \\
\hline Barriers & $\begin{array}{l}\text { Factors that prevent or limit translation of motivating } \\
\text { values into action. }\end{array}$ \\
\hline $\begin{array}{l}\text { Relational } \\
\text { enablers/barriers }\end{array}$ & $\begin{array}{l}\text { Factors that support or prevent participation and } \\
\text { consist of a relationship; e.g., a relational enabler may } \\
\text { be an active and supportive social network, a relational } \\
\text { barrier may be a dysfunctional interpersonal } \\
\text { relationship that prevents access to a particular mode } \\
\text { of participation. }\end{array}$ \\
\hline
\end{tabular}

A local community group, the Macdonald Valley Association (MVA), has also successfully received funding from the NSW Environmental Trust (partnered with Local Government and LLS) to undertake valley-wide removal of particular weed species, e.g., tree of heaven (Ailanthus altissima) and false bamboo (Arundo donax). The MVA is not an environmental organization, but a community advocacy group. The MVA has provided a platform for a small number of landholders to promote river rehabilitation in their community. Individual landholders have also independently applied for, and received, grants to undertake work on their properties. Supported by these grants, and by government collaborators, the community of the Macdonald Valley is leading a range of environmental programs from the
Fig. 1. (a) Map of the Macdonald River showing town of St Albans, where majority of residents live. Satellite imagery sourced from Google Earth. (b) The Macdonald River looking upstream at town of St Albans. Note in-channel sand in form of sediment slug, which is an impact of historical flooding. Geomorphic recovery has since begun in the form of low-flow channel redefinition and bench building in-channel (see Mould and Fryirs 2018).
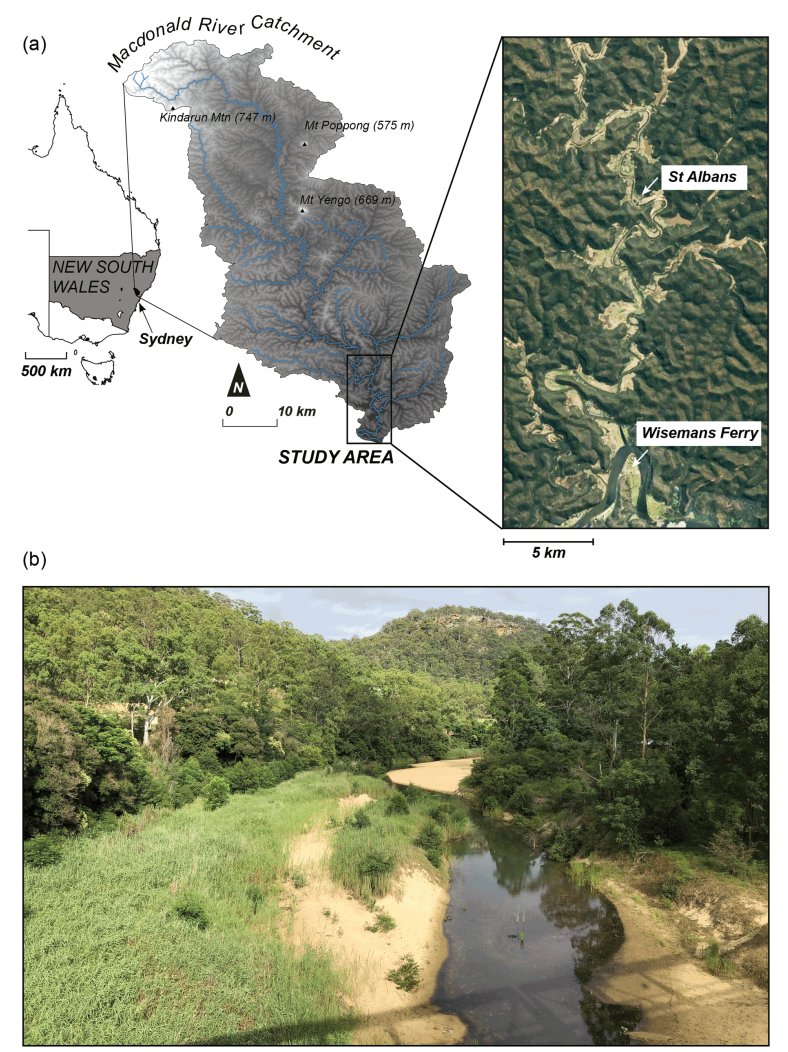
Fig. 2. Roles of organizations and groups involved in the participatory rehabilitation of Macdonald River, where New South Wales Local Land Services exist as a middle-ground nexus for funding and coordination of works. Ovals contain groups of actors in river management, connected by lines describing the primary relationships between actors.

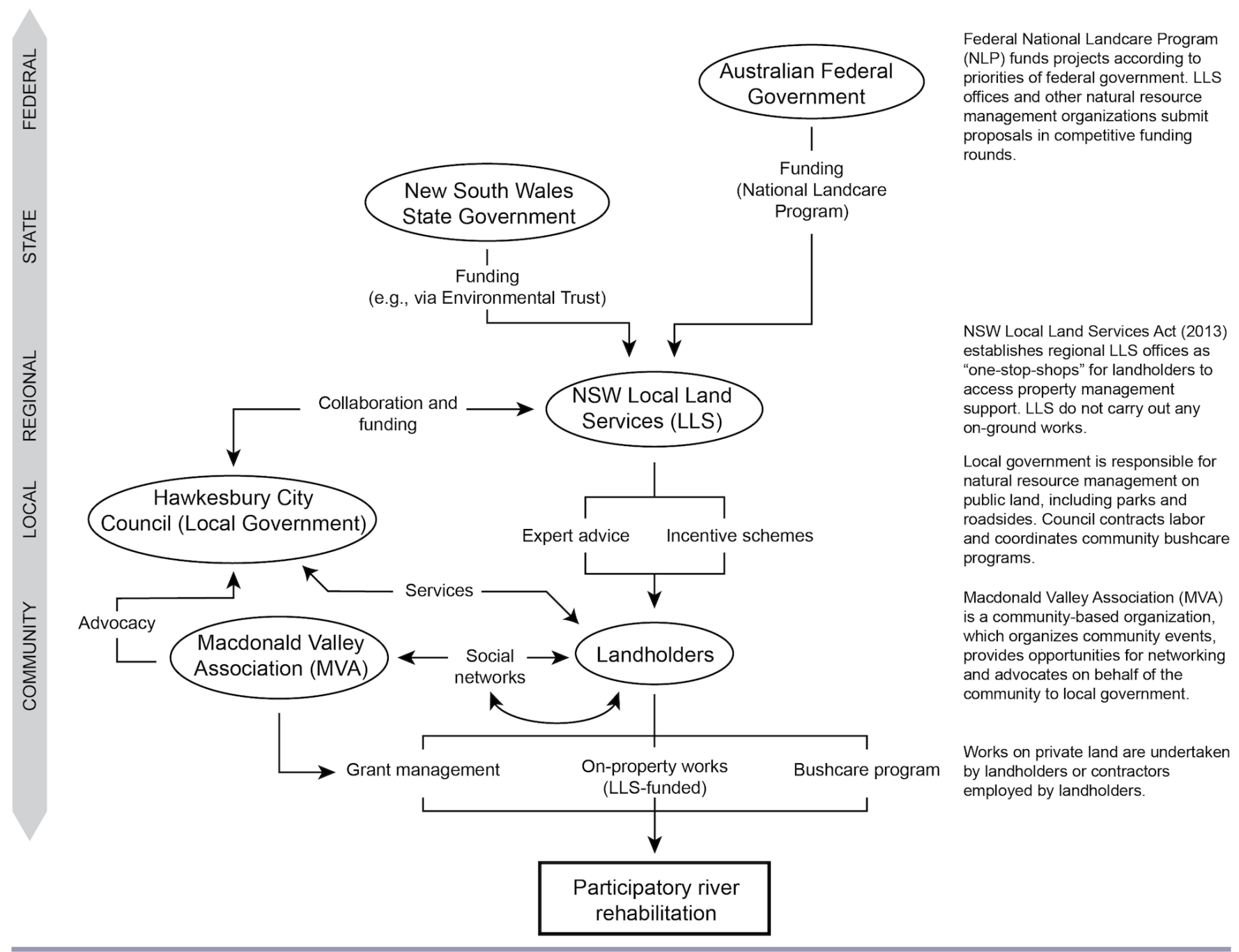

bottom-up. The river management structure described here is relatively common in Australia and has been characterized as a "middle-ground" approach (Gregory et al. 2011, Hassenforder et al. 2019). In such a system, top-down (government-led) processes meet with bottom-up (community-led) processes in the middleground. Middle-ground decision making is often scaled at the catchment level, ideally allowing integration of values and processes from, and across, a range of scales (Gregory et al 2011). The reliance on participation from private landholders in Australia makes it critical that they are supported in participation. For this reason, environmental managers must understand the factors that influence how and why landholders are likely or unlikely to participate (c.f. Selinske et al. 2015, Horangic et al. 2016).

\section{RESULTS AND INTERPRETATION}

Interviews with landholders revealed motivating values driving participation or nonparticipation, as well as the outcomes or benefits of participation for individuals and the community.
Motivating values held by participants push them to act, e.g., to fix a perceived problem. Outcomes are more akin to rewards for participation that pull or entice participants toward action.

\section{Motivating values for participation in river management}

Visions for the river

The most common reason for (non)participation was a particular vision for how the river "should" be. These visions implied relational values concerning particular relationships with the river, flora/fauna, and broader landscape (Table 3). These spanned concerns for "how things used to be," loss of aesthetic beauty or amenity, and a desire to care for the landscape and the flora/fauna. In some cases, these relational values were expressed alongside intrinsic values, e.g., inherent value of wildlife, or instrumental values, e.g. access to river crossing.

Respondents revealed different personal baselines against which the contemporary river was evaluated. For nonparticipants, these baselines tended to correspond with how the river appeared in 
Table 3. Motivating visions for the river.

\begin{tabular}{|c|c|c|c|}
\hline Vision & Associated values & $\begin{array}{l}\text { Alignment of } \\
\text { vision with } \\
\text { rehabilitation } \\
\text { agenda }\end{array}$ & Excerpt from interview \\
\hline $\begin{array}{l}\text { Channel should be shallow and } \\
\text { river clear of vegetation other } \\
\text { than grasses (pre-1949 flood } \\
\text { condition) }\end{array}$ & - Access to river (instrumental) & Nonalignment & $\begin{array}{l}\text { "If [the channel] were deeper right down it'd be no good for } \\
\text { me to cross in my tractor" - Respondent } 13 \text {. }\end{array}$ \\
\hline $\begin{array}{l}\text { River should be vegetated with } \\
\text { soft vegetation only: tea trees, } \\
\text { grasses, reeds (early recovery } \\
\text { condition) }\end{array}$ & $\begin{array}{l}\text { - Stability and safety (instrumental) } \\
\text { - The way things used to be (relational) }\end{array}$ & Weak & $\begin{array}{l}\text { "I don't believe in gum trees on the river ... because they're too } \\
\text { rigid; if something gets caught alongside them and the flood } \\
\text { starts to gouge it out ... I think reeds, tea trees, anything that } \\
\text { bends with the water ... if the river's getting deeper that's a } \\
\text { positive, because that's how it used to be" - Respondent } 8 \text {. } \\
\text { "You just don't need all this stuff [complex vegetation]. Let it } \\
\text { go back to grass and tea trees ... it used to be beautiful when it } \\
\text { was like that" - Respondent } 12 \text {. }\end{array}$ \\
\hline $\begin{array}{l}\text { River should be well-vegetated } \\
\text { with diverse vegetation } \\
\text { communities (fully recovered } \\
\text { condition) }\end{array}$ & $\begin{array}{l}\text { - Biodiversity, "nativeness" (intrinsic) } \\
\text { - Caring for wildlife (relational) }\end{array}$ & Strong & $\begin{array}{l}\text { "You become aware of this whole community ... different tree } \\
\text { species come into prominence at different times. And you'd be } \\
\text { missing all that [if weeds took hold] ... and we notice, the birds } \\
\text { notice ... you are actually creating, a bit more like a quilt, as } \\
\text { opposed to just one color, just one fabric, one texture" - } \\
\text { Respondent } 1 . \\
\text { "We love the place and don't want it to be taken over by } \\
\text { weeds." } \\
\text { "We've got amazing numbers of birds here." } \\
\text { "And we've started to have koalas come back ... so we planted } \\
\text { a whole - our tree avenues that we planted, we planted species } \\
\text { that they eat, too." - Respondents } 7 \text { and } 9 . \\
\text { "The bird life is incredible. The native fauna is very } \\
\text { important." - Respondent } 2 \text {. }\end{array}$ \\
\hline
\end{tabular}

their earliest experiences of it and a desire to maintain the river in that remembered condition. For example, Respondent 12 arrived in the valley in the 1990s, when there was relatively little vegetation in the riparian zone (dominantly grasses and tea trees). This respondent "fell in love with" the river at this time and would like to see it return to that state. On the other hand, Respondent 13 remembers the denuded riparian zone prior to and closely following the 1949-1955 floods and continues to maintain the riparian zone in this condition, as did their father.

In contrast, active participants in river management programs preferred a vision for the river that closely aligns with the goals of the recovery-based management program, an imagined, future version of the river that has not yet been seen. Many of the participants arrived in the valley after geomorphic recovery had already begun, so their baselines contain densely vegetated but weed impacted riparian zones. A cleared riparian zone did not typically factor into their range of options for how the river should be, so improvement of vegetation cover and species mix was their most preferred management action. Responses reflect a possible "shifting baselines" effect, where what is "normal" depends on the timing of an individual's formative experiences when developing a relationship with that place (c.f. Pauly 1995, Brierley and Fryirs 2016).

\section{Responsibilities}

Many respondents expressed a sense of responsibility, or duty of care, which influenced them to act in particular ways. Participants in river management often saw their work as fulfilling a responsibility to the future (future of river, landscape, and future generations). In contrast, responses from nonparticipants were often expressed as a responsibility to the past (how the river used to be or how previous generations of farmers used or cared for the land). However, it would be overly simplistic to generalize the two groups of participants and nonparticipants as being only future- or past-focused; the future of the valley and its community was a concern expressed by most respondents, regardless of their participation status. Also common to these landholders was a sense of stewardship, that they were acting as stewards of their properties and in the best interests of the land. Embedded in this expression is an underlying relational value for caring, or that it is good to be in a caring relationship with the landscape and community (c.f. Jax et al. 2018, West et al. 2018). Examples include valuing of connection with ancestors, e.g., through traditional farming practices, and valuing a sustainable relationship with their environment, e.g. through rehabilitation, consistent with identity as a responsible landholder (Table 4).

Responses also revealed nonrelational values; for example, nonparticipants expressed concern for flood damage, access to the river, and use of its water and riparian zones (largely instrumental values for safety, use, and access). Participants in rehabilitation were also concerned with risk of flood impacts, but they tended to frame this in terms of damage to the river and a loss of progress in river recovery, rather than risk to human safety or infrastructure. 
Table 4. Motivating responsibilities.

\begin{tabular}{|c|c|c|}
\hline Responsibility & Associated values & Excerpt from interview \\
\hline $\begin{array}{l}\text { Identity as generational farmer, } \\
\text { carrying on traditional practices }\end{array}$ & $\begin{array}{l}\text { - Family tradition (relational) } \\
\text { - Safety and stability (intrinsic) }\end{array}$ & $\begin{array}{l}\text { "My father wouldn't let a tree grow close to the river because he used to } \\
\text { reckon it would wash around, cause things to get washed away" - } \\
\text { Respondent } 13 \text {. }\end{array}$ \\
\hline $\begin{array}{l}\text { Responsibility to future generations, } \\
\text { future of river }\end{array}$ & $\begin{array}{l}\text { - Care for future generations } \\
\text { (relational) } \\
\text { - Care for future of river (relational) }\end{array}$ & $\begin{array}{l}\text { "We can't let this [weed infestation] happen ... in } 50 \text { years' time my son will } \\
\text { be a very old man and we'll be long gone ... the river will still be here ... so } \\
\text { my vision is always to "rescue the future"” - Respondent } 6 .\end{array}$ \\
\hline Identity as responsible landholder & $\begin{array}{l}\text { - Care for environment as a steward } \\
\text { (relational) }\end{array}$ & $\begin{array}{l}\text { "If you own a property and let it go to wrack and ruin like that, then you } \\
\text { shouldn't own it." } \\
\text { "Yeah, it's like, you can't just turn your shoulders." - Respondents } 4 \text { and } 1 .\end{array}$ \\
\hline Responsibility for "doing your bit" & $\begin{array}{l}\text { - Contribution to a greater, shared } \\
\text { effort (relational) }\end{array}$ & $\begin{array}{l}\text { "It's our little bit; it's our little piece. And it's not too much when you break } \\
\text { it down to that." Respondent } 1 \text {. }\end{array}$ \\
\hline
\end{tabular}

\section{Outcomes of participation in river rehabilitation}

Respondents who participate in river rehabilitation expressed both personal outcomes (for the individual) and social outcomes (for the community) resulting from their participation. The outcomes of participation reflected relational values. Relational values included building and enriching a connection to the physical landscape through work, a sense of personal satisfaction in contributing to the program and the benefits of breaking down barriers and bonding with members of the community through shared experience (valuing social connection and community; Table 5).

\section{Enablers and barriers for participation in river management}

Enablers are factors that assist in translating motivating values into action. They may also help to overcome barriers to participation. Enablers and barriers identified in this case study are institutional, economic, or relational, i.e., it is a relationship or social interaction that enables participation (Table 6). A key institutional enabler is the availability of incentive grants and the support from LLS that accompanies this finance. However, this institutional enabler is more accessible and attractive to potential participants because of additional relational enablers, an example of which is the proactive approach and long-term relationship building undertaken by the community's Local Land Services Officer. Barriers to participation are also often relational, stemming from a lack of connection with opportunities to participate or a desire to remain separate from particular kinds of involvement with community or government.

\section{DISCUSSION}

This case highlights the importance of relational values for understanding the dynamics of participation in river management, conceptualized in Figure 3. First, relational values are significant motivators for participation and include visions for how the river should be and feelings of responsibility. Second, motivating values are translated into actions via enablers, including social relationships within a community and relationships with government and government employees. Third, participants report beneficial outcomes of participation, which appeal to particular relational values, for example, valuing connection with community or connection with place. We present this model as a basis for discussing the importance of relational values in participatory river management and how programs and initiatives aimed at facilitating this could better account for, and respond to, relational values as part of a relational approach to river management.
Table 5. Outcomes of participation.

\begin{tabular}{ll}
\hline \hline $\begin{array}{l}\text { Outcome of participation (and } \\
\text { associated values) }\end{array}$ & Excerpt from interview \\
\hline Connection to place (relational) & $\begin{array}{l}\text { "You're in the dirt on your hands } \\
\text { and knees on different places and ... } \\
\text { you feel a sense of, I don't know, } \\
\text { responsibility or connection, or a } \\
\text { feeling that "I can do something } \\
\text { here and I can contribute"” - } \\
\text { Respondent 10. } \\
\text { "I get a buzz out of planting trees, I } \\
\text { have to say" - Respondent 5. } \\
\text { "There's massive social benefits ... } \\
\text { to use the cliché, it breaks down } \\
\text { bersonal satisfaction drawn from } \\
\text { contributing (relational) } \\
\text { (relational) } \\
\text { anyone who gets their hands dirty } \\
\text { and doesn't mind squatting down in } \\
\text { a huge pile of weeds ... we are } \\
\text { bonded by our physicality and our } \\
\text { ability, and our love of what we're } \\
\text { doing" - Respondent } 6 .\end{array}$ \\
\hline
\end{tabular}

\section{Importance of relational values in participatory river management}

Potential participants hold various values that will either motivate or demotivate them to participate. In order to help translate motivating values into participatory action, facilitators of participation need to understand the barriers that prevent participation and the enablers that potentially overcome barriers. Knowing which enablers might be most effective in a given setting relies on a firm understanding of the particular values held by a community or individual, which will influence the ways people may respond to potential enablers (c.f. Chapman et al. 2019, Hassenforder et al. 2019, Grassini 2019).

In this case study, the majority of enablers identified were relational in nature. Although the existence of a financial incentive scheme overcomes the financial barrier to participation on private property, interpersonal relationships provide very powerful additional enablers. Relational enablers may be particularly powerful because they simultaneously address a practical need to access resources, e.g., funding or information, as well as achievement of additional "soft" benefits, which satisfy individuals' relational values (Measham and Barnett 2008, Chan et al. 2016). The relevant relational values are revealed in 
Fig. 3. The process by which landholders' motivating values are translated into direct participation in river management (actions) via enablers in the middle-ground. Enablers help to overcome barriers to participation. Direct participation in rehabilitation has personal and social outcomes, which may result in evolution of motivating values. New motivations further drive ongoing participation, and participation may rely less on support from middle-ground agencies as individual and community capacity builds. Dashed lines indicate possible pathways to participation enabled by named factors. Size of "bubbles" in "actions" indicates relative rate of participation in each action. "(R)" indicates a relational factor, e.g., relational value, enabler, barrier, or outcome. MVA = Macdonald Valley Association; LLS = Local Land Services.

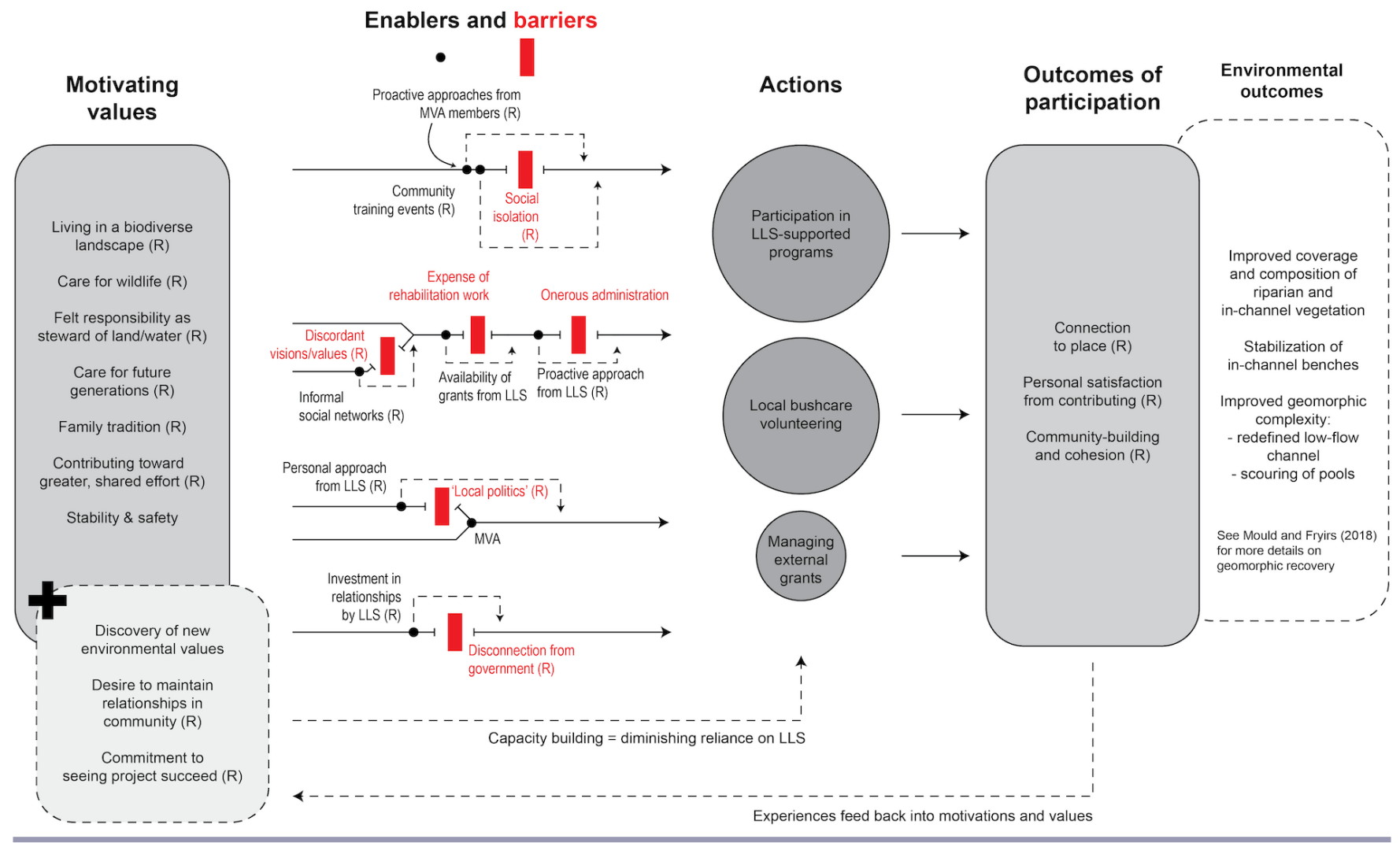

motivating values (left side of Fig. 3) and outcomes of participation (right side of Fig. 3). For example, motivations associated with a sense of responsibility as a steward reflect relational values for relationships of care (Jax et al. 2018; Table 3). Similarly, the outcome of "community building and cohesion" (Fig. 3) reflects valuing of relationships with one's community (Table 4). Effective facilitation of participation will therefore aim to understand and adapt to the full range of values, including relational values, that influence participation, recognizing that relational values are important drivers of behavior.

The examples of "enablers and barriers" in Figure 3 (see also Table 6) demonstrate the enabling potential of dedicated river management practitioners who are willing to invest in building strong relationships with communities (and who are supported by their employers to do so). These individuals play a key enabling role, helping to address instrumental, e.g., financial or intellectual, and relational values in order to facilitate participatory actions. Participation in this case study is motivated by a wide range of values, but these motivating values are effectively channeled into a coherent range of participatory actions (Fig. 3). The programs that facilitate these actions enable individuals to express their values through action. Enablers appear to be effectively supporting individuals to participate in these programs, participants are reporting outcomes that address their values, and these actions are contributing to recovery of the Macdonald River (Fig. 3; Mould and Fryirs 2018).

It is important to understand the outcomes reported by participants because they reflect experiences associated with their relational values and, as a result, may further motivate participants to remain involved in river management or even increase their involvement (c.f. Gooch 2003). This possibility is represented as a feedback loop in Figure 3, wherein the outcomes experienced by participants contribute to and reinforce their motivations. Over time, it is possible that such a feedback loop could strengthen the will and capacity for landholders to participate in river management, resulting in less reliance on enablers provided by facilitators such as river management professionals (Measham 2007).

Working with relational values as part of a relational approach to river management

Having highlighted the important role played by relational values and relationships in participatory river management, we now 
Table 6. Enablers and barriers for participation. LLS = Local Land Services; MVA = Macdonald Valley Association.

\begin{tabular}{ll}
\hline \hline Barrier & Enabler \\
\hline Expense of rehabilitation work (economic barrier): & Availability of grants (economic/institutional enabler): \\
Local government enforces restrictions on methods for & Matched funding from LLS supports landholders and \\
removal of vegetation in riparian zones to protect native & encourages work to be completed within set time frames. \\
vegetation and bank stability. &
\end{tabular}

Onerous administration (institutional/economic barrier): Applications for grants to manage riparian vegetation can be complicated and time-consuming for landholders to complete.

Isolation from community and information (relational barrier): New landholders may not know what opportunities are available to them for property management or who to approach for help.
Proactive approach from LLS Officer (relational enabler): LLS Officers have taken a proactive approach to landholder engagement, providing information to potential participants and assisting with preparation of grant applications.

Proactive approach from LLS officer (relational enabler): (see above)

Proactive approach from local MVA members (relational enabler):

Local MVA members contact new landholders to welcome them to the community, inform them on the functions of the MVA, and introduce available property management programs.

Investment in relationships (relational enabler)

Disconnection from government (relational barrier) LLS Officer invests time in visiting and talking with Macdonald Valley has a history of being "forgotten" government, and some landholders would rather be "left alone."

Discordant visions (relational barrier): Some landholders' visions for how the river could be are

Lack of knowledge in community (relational/ institutional barrier): Landholders (especially new to the area) may not have specific knowledge or experience in river rehabilitation. discordant with the aims of rehabilitation programs.
Community training events (relational/institutional Informal social networks (relational enabler): Reluctan landholders perhaps cannot be reached directly by programs but may become involved through other landholders that they trust, or by observing results for themselves.

enabler): MVA, LLS, and individual landholders organize community training events, which allow landholders to learn from experts, exchange information with peers, and build relationships.
Excerpt from interview

"When a new person comes along and there are 50 species of weeds and natives [in their riparian zone] due to the previous owner's neglect, then they've got quite a lot of work to do. So we get grants ... if you read right through [the legislation] and obey it, essentially you're maintaining your riverbank by ... poisons and hand labor. That's really expensive or an unexpected expense for a new purchaser." - Respondent 3.

"They [LLS Officer] actually came and had a visit on the property ... I thought I'd have to put together an application, but [LLS Officer] said, "Oh no, I do that." ... that was very positive ...nearly a whole day, it took ... that's really important." - Respondent 1 .

"[The MVA] are quite active. Whenever a new person moves in, they go and see them and talk to them ... we were interested in getting involved locally, and when they said there was something about weed control or nature ... it was very interesting [to me]." - Respondent

"The MVA are very quick to pick up on new people, and they get involved, and the word spreads." - Respondent 15 .

"I think that [LLS Officer] would tell you that for [them] to work in the valley, it's all about the people, the connections and how you relate to people."

Respondent 10.

"I think this particular relationship between us [LLS] and the Macdonald Valley is quite unique ... I'm always available, and I make time to go up there." - Respondent 15 .

"A lot of people say you've got to have trees and all that to hold the banks, but all of my river, I don't let any tree grow where it's going to wash [away soil in flood]." Respondent 13.

"There are some people we won't influence. But everyone else seems to be open to maybe influence by neighbors, you just don't know why someone rings up out of the blue [to ask for advice]." - Respondent 15. "When you look at the grant we had ... the incredible benefit that's come out of that grant in terms of our transformation, in terms of knowledge and what we've done with that." - Respondent 1.

"In one eight-week course, you went to eight differen properties so there was lots of networking ... it was really good. They [landholders] talk amongst themselves. I didn't have to do anything ... they're a really cohesive community and they talk to each other." - Respondent 15.

"I don't know what's going on [with the MVA]. There's

Local politics (relational barrier): Some landholders were reluctant to participate because of environmental issues being attached to the MVA, which was associated with "local politics" they did not wish to be involved with.
A personal approach from LLS and informal social networks (relational enabler): Efforts by LLS officer landholders to approach individual landholders and develop personal relationships may prevent rehabilitation agenda from being "captured" by any particular group of local landholders.
14.

"The main area where there's room for improvement is in human relations ... administration of the grant locally has been problematic with different agendas in play." Respondent 6 .

Although LLS Officers try to remain proactive, they increasingly do this with fewer resources and in many cases can often no longer provide the level of support described by Respondent 1 . 
consider opportunities and challenges for practitioners to facilitate participation. We describe a relational approach to river management, wherein practitioners are encouraged to recognize relational values and prioritize enabling relationships as core activities, putting relationships at the center of river management practice.

\section{Recognize relational values}

A relational approach to river management means paying attention to, and responding to, the specific and dynamic social relationships through which meaning is made, decision making is negotiated, and participation may be practiced (Rhoads et al. 1999, Rogers 2006, Emery et al. 2013, Lave 2016). It requires a commitment to listening as a basis for understanding (Howitt 2019) and care must be taken to build relationships of trust with individuals (Brandenburg and Carroll 1995) in order to understand values and respond to them. In this case study it was necessary to spend time and establish rapport with individuals in order to gain access to their stories and experiences, and to interpret them accurately. In practice, an approach to supporting participation that recognizes the importance of relationship development is well demonstrated by the LLS Officer working in the Macdonald Valley. Many participants regarded the Officer as a trustworthy collaborator, noting the commitment demonstrated by long-term engagement in that role ( $>10$ years; see Table 6 ). The LLS Officer explained that they work hard to always be available to community members and to make the effort for faceto-face visits, particularly with new landholders. Continuity of employment and a personal commitment to the community were identified by the LLS Officer and participants interviewed as critical to successful practice. It is important to note that, at least in Australia, the environmental management industry is increasingly characterized by short-term employment and organizational restructures that disrupt the potential for formation and maintenance of meaningful relationships between practitioners and communities. This is a significant challenge that requires attention from higher level managers and policy makers.

\section{Prioritize enabling relationships}

Incentive schemes to encourage participation in voluntary programs may come and go, and levels of financial support may change over time, potentially influencing rates of participation. Therefore, a multifaceted strategy to encouraging participation will always be more effective in the long term than relying on a single-focus program. Similar points have been made by Barnes et al. (2013) and Curtis and Robertson (2003) in terms of providing choices to landholders, and by Moore et al. (2018) in advocating for more flexibility in incentive schemes particularly in times of environmental pressure. We contribute the additional suggestion that formal mechanisms for participation can be underpinned and enabled by relational approaches, working to ensure that there are also informal incentives for landholders to participate, that appeal to relational values (see also Bremer et al. 2018, Chapman et al. 2019).

Prioritizing enabling relationships means not only developing strong relationships between potential participants and river management professionals, but also recognizing, supporting, and resourcing existing and potential social networks that could carry participation within a community. Respondents identified community building and sharing of knowledge and skills as important outcomes of participation (Fig. 3; see also Measham and Barnett 2008). Respondents related these benefits to ad hoc activities as well as community training events that were coorganized by local people and government. The events that brought landholders together to learn from each other's experiences ("social learning"; Pahl-Wostl et al. 2007, Reed et al. 2010) were catalytic for some landholders becoming involved in river management activities. Over time, there is potential for such events to build and maintain social networks in a community of practice, wherein informal networks can become productive and dynamic platforms for knowledge exchange through social learning (Wenger 2010). Different community networks may have different characteristics and needs (Lauber et al. 2008), including diverse relational values that motivate action (Fig. 3). Therefore, practitioners should be looking for ways to support their community networks in ways that are relevant to those communities, informed by an approach to community engagement that emphasizes relationship building as a basis for understanding.

\section{Overcoming barriers}

For many potential participants, the benefits of participation will likely outweigh the barriers, provided that enabling mechanisms for participation are in place. However, some landholders' values act as barriers to participation because they are not closely aligned with the goals of rehabilitation. It is important to note that the enabling pathways in Figure 3, depicted as overcoming barriers, are not universal.

Some potential participants may not be opposed to river rehabilitation in principle, but are initially uninterested or wary of a particular environmental agenda. A traditional approach to this problem might assume that filling a deficit of landholder knowledge will overcome reluctance to participate (see Sturgis and Allum 2004, Eden and Tunstall 2006, Irwin 2014). Although landholder knowledge is an important factor influencing participation (Curtis and Robertson 2003), a relational approach to river management provides an additional, alternative way of conceptualizing this problem by aiming to understand and respond to the relational values that may be influencing landholder choices. Value conflicts involving relational values (Chapman et al. 2019) or failure to understand the impacts of environmental programs on existing relational values (Bremer et al. 2018) are examples of barriers that may be frequently overlooked. In these cases, a focus on relationships and dialogue (c.f. Mould et al. 2018) is likely to be helpful for understanding the relational values that influence participation and identifying additional or alternative enablers that recognize and work with the relational values that are important in a given place (c.f. Bremer et al. 2018, Chapman et al. 2019).

Attention should also be paid to providing the necessary support, where possible, to the informal social networks by which nonparticipants may observe or hear about the benefits of participation from peers that they trust (e.g., Kuhfuss et al. 2016). Understanding the social relationships that compose existing social networks will help to develop strategies that can support exchange of knowledge and ideas within a community. However, although social networks can help to overcome barriers to participation in some settings, it also must be recognized that particular social networks provide a barrier to participation for 
others (c.f. Horangic et al. 2016). For example, nonparticipants who identified "local politics" as a factor preventing their involvement in existing river management programs may avoid involvement because of their association with particular social networks or groups. In these cases, individual relationship building will be important to ensure that participation is not "captured" by community groupings, as in a "representative" model of public engagement (see Larson and Lach 2008). Reaching landholders who are less forthcoming, in either case, will likely be more successful when attention is given to understanding how particular relational values may be manifest as either barriers or enablers, depending on the context.

\section{CONCLUSION}

Regardless of the structures that dictate river management practices in specific settings, e.g., top-down, bottom-up, or middle-ground, participation is an important part of achieving ongoing and effective river management. Effective participation strategies should understand diverse relational values that contribute to the social context of river management, enhance enabling processes, and work with social barriers to support participation. For landholders, participation is more than an activity undertaken to improve environmental condition; it is innately linked to relational values for particular kinds of relationships between people and place. Approaching participation through the lens of relational values engenders opportunities for improving river management practice, making it more responsive and adaptive to the particular values that motivate action. Structures and systems designed to support participation should enact a relational approach in order to be as effective as possible. Recognizing relational enablers and barriers and prioritizing relationships can incentivize participation and help to overcome barriers between landholders' motivating values and coherent, collective river rehabilitation actions in the pursuit of sustainable socio-environmental systems.

\section{Responses to this article can be read online at: http://www.ecologyandsociety.org/issues/responses. php/11505}

\section{Acknowledgments:}

The authors wish to thank the people of the Macdonald Valley, who gave up their time to participate in interviews for this research. Simon Mould's PhD candidature was supported by the Australian Government's Research Training Program. This research was funded by the Department of Environmental Sciences, Macquarie University. Ethics approval was granted by the Macquarie University Human Research Ethics Committee (Ref. 5201700048).

\section{Data Availability Statement:}

The datalcode that support the findings of this study are available on request from the corresponding author, SM. The datalcode are not publicly available because of their containing information that could compromise the privacy of research participants.

\section{LITERATURE CITED}

Allen, K. E., C. E. Quinn, C. English, and J. E. Quinn. 2018. Relational values in agroecosystem governance. Current Opinion in Environmental Sustainability 35:108-115. https://doi. org/10.1016/j.cosust.2018.10.026

Arnstein, S. R. 1969. Ladder of citizen participation. Journal of the American Institute of Planning 35(4):216-224. https://doi. org/10.1080/01944366908977225

Barnes, A. P., L. Toma, J. Willock, and C. Hall. 2013. Comparing a 'budge' to a 'nudge': farmer responses to voluntary and compulsory compliance in a water quality management regime. Journal of Rural Studies 32:448-459. https://doi.org/10.1016/j. jrurstud.2012.09.006

Baxter, J., and J. Eyles. 1997. Evaluating qualitative research in social geography: establishing 'rigour' in interview analysis. Transactions of the Institute of British Geographers 22(4):505-525. https://doi.org/10.1111/j.0020-2754.1997.00505.x

Brandenburg, A. M., and M. S. Carroll. 1995. Your place or mine?: The effect of place creation on environmental values and landscape meanings. Society \& Natural Resources 8(5):381-398. https://doi.org/10.1080/08941929509380931

Bremer, L. L., K. A. Brauman, S. Nelson, K. M. Prado, E. Wilburn, and A. C. O. Fiorini. 2018. Relational values in evaluations of upstream social outcomes of watershed payment for ecosystem services: a review. Current Opinion in Environmental Sustainability 35:116-123. https://doi.org/10.1016/j.cosust.2018.10.024

Brierley, G. J., and K. A. Fryirs. 2016. The use of evolutionary trajectories to guide 'moving targets' in the management of river futures. River Research and Applications 32(5):823-835. https:// doi.org/10.1002/rra.2930

Brierley, G., M. Hillman, and K. Fryirs. 2006. Knowing your place: an Australasian perspective on catchment-framed approaches to river repair. Australian Geographer 37(2):131-145. https://doi.org/10.1080/00049180600699352

Carr, A. 2002. Grass roots and green tape: principles and practices of environmental stewardship. Federation Press, Annandale, Australia.

Chan, K. M. A., P. Balvanera, K. Benessaiah, M. Chapman, S. Díaz, E. Gómez-Baggethun, R. Gould, N. Hannahs, K. Jax, S. Klain, G. W. Luck, B. Martín-López, B. Muraca, B. Norton, K. Ott, U. Pascual, T. Satterfield, M. Tadaki, J. Taggart, and N. Turner. 2016. Opinion: Why protect nature? Rethinking values and the environment. Proceedings of the National Academy of Sciences USA 113(6):1462-1465. https://doi.org/10.1073/pnas.1525002113

Chan, K. M. A., R. K. Gould, and U. Pascual. 2018. Editorial overview: Relational values: what are they, and what's the fuss about? Current Opinion in Environmental Sustainability 35:A1A7. https://doi.org/10.1016/j.cosust.2018.11.003

Chapman, M., T. Satterfield, and K. M. A. Chan. 2019. When value conflicts are barriers: Can relational values help explain farmer participation in conservation incentive programs? Land Use Policy 82:464-475. https://doi.org/10.1016/j.landusepol.2018.11.017

Corbin, J. M., and A. Strauss. 1990. Grounded theory research: procedures, canons, and evaluative criteria. Qualitative Sociology 13(1):3-21. https://doi.org/10.1007/bf00988593 
Curtis, A., and A. Robertson. 2003. Understanding landholder management of river frontages: the Goulburn Broken. Ecological Management \& Restoration 4(1):45-54. https://doi.org/10.1046/ j.1442-8903.2003.t01-1-00137.x

Eden, S., and S. Tunstall. 2006. Ecological versus social restoration? How urban river restoration challenges but also fails to challenge the science - policy nexus in the United Kingdom. Environment and Planning C: Politics and Space 24:661-680. https://doi.org/10.1068/c0608j

Emery, S. B., M. T. Perks, and L. J. Bracken. 2013. Negotiating river restoration: the role of divergent reframing in environmental decision-making. Geoforum 47:167-177. https://doi.org/10.1016/ j.geoforum.2013.01.008

Erskine, W. D. 1986. River metamorphosis and environmental change in the Macdonald Valley, New South Wales, since 1949. Geographical Research 24(1):88-107. https://doi.org/10.1111/ j.1467-8470.1986.tb00513.x

Erskine, W., and M. D. Melville. 1983. Impact of the 1978 floods on the channel and floodplain of the lower Macdonald River, N. S.W. Australian Geographer 15(5):284-292. https://doi. org/10.1080/00049188308702828

Euler, J., and S. Heldt. 2018. From information to participation and self-organization: visions for European river basin management. Science of the Total Environment 621:905-914. https://doi.org/10.1016/j.scitotenv.2017.11.072

Fryirs, K. A., B. Chessman, M. Hillman, D. Outhet, and A. Spink. 2008. The Australian river management experience. Pages 149-173 in G. J. Brierley and K. A. Fryirs, editors. River futures: an integrative scientific approach to river repair. Island, Washington, D.C., USA.

Gooch, M. 2003. A sense of place: ecological identity as a driver for catchment volunteering. Australian Journal of Volunteering 8 (2):23-32.

Grassini, L. 2019. Participatory water governance between theories and practices: learning from a community-based initiative in India. International Journal of Water Resources Development 35(3):404-429. https://doi.org/10.1080/07900627.2$\underline{017.1354761}$

Gregory, C., G. Brierley, and R. Le Heron. 2011. Governance spaces for sustainable river management. Geography Compass 5 (4):182-199. https://doi.org/10.1111/j.1749-8198.2011.00411.x

Hassenforder, E., D. Clavreul, A. Akhmouch, and N. Ferrand. 2019. What's the middle ground? Institutionalized vs. emerging water-related stakeholder engagement processes. International Journal of Water Resources Development 35(3):1-18. https://doi. org/10.1080/07900627.2018.1452722

Head, B. W. 2007. Community engagement: participation on whose terms? Australian Journal of Political Science 42 (3):441-454. https://doi.org/10.1080/10361140701513570

Henry, H. M. 1977. Catastrophic channel changes in the Macdonald Valley, New South Wales, 1949-1955. Journal and Proceedings, Royal Society of New South Wales 110:1-16.
Horangic, A., K. A. Berry, and T. Wall. 2016. Influences on stakeholder participation in water negotiations: a case study from the Klamath Basin. Society \& Natural Resources 29 (12):1421-1435. https://doi.org/10.1080/08941920.2016.1144837

Howitt, R. 2019. Unsettling the taken (for granted). Progress in Human Geography 44(2):193-215. https://doi.org/10.1177/03091$\underline{32518823962}$

Irwin, A. 2014. From deficit to democracy (re-visited). Public Understanding of Science 23(1):71-76. https://doi. org/10.1177/0963662513510646

Jax, K., M. Calestani, K. M. A. Chan, U. Eser, H. Keune, B. Muraca, L. O'Brien, T. Potthast, L. Voget-Kleschin, and H. Wittmer. 2018. Caring for nature matters: a relational approach for understanding nature's contributions to human well-being. Current Opinion in Environmental Sustainability 35:22-29. https:// doi.org/10.1016/i.cosust.2018.10.009

Jones, K., and D. Tobin. 2018. Reciprocity, redistribution and relational values: organizing and motivating sustainable agriculture. Current Opinion in Environmental Sustainability 35:69-74. https://doi.org/10.1016/j.cosust.2018.11.001

Kuhfuss, L., R. Préget, S. Thoyer, and N. Hanley. 2016. Nudging farmers to enrol land into agri-environmental schemes: the role of a collective bonus. European Review of Agricultural Economics 43(4):609-636. https://doi.org/10.1093/erae/jbv031

Larson, K. L., and D. Lach. 2008. Participants and nonparticipants of place-based groups: an assessment of attitudes and implications for public participation in water resource management. Journal of Environmental Management 88 (4):817-830. https://doi.org/10.1016/j.jenvman.2007.04.008

Lauber, T. B., D. J. Decker, and B. A. Knuth. 2008. Social networks and community-based natural resource management. Environmental Management 42(4):677-687. https://doi.org/10.1007/s00267-008-9181-8

Lave, R. 2016. Stream restoration and the surprisingly social dynamics of science. Wiley Interdisciplinary Reviews: Water 3 (1):75-81. https://doi.org/10.1002/wat2.1115

Maynard, C. M. 2013. How public participation in river management improvements is affected by scale. Area 45 (2):230-238. https://doi.org/10.1111/area.12015

Measham, T. G. 2007. Building capacity for environmental management: local knowledge and rehabilitation on the Gippsland Red Gum Plains. Australian Geographer 38 (2):145-159. https://doi.org/10.1080/00049180701392758

Measham, T. G., and G. B. Barnett. 2008. Environmental volunteering: motivations, modes and outcomes. Australian Geographer 39(4):537-552. https://doi.org/10.1080/00049180802419237

Mehring, P., H. Geoghegan, H. L. Cloke, and J. M. Clark. 2018. What is going wrong with community engagement? How flood communities and flood authorities construct engagement and partnership working. Environmental Science \& Policy 89:109-115. https://doi.org/10.1016/j.envsci.2018.07.009

Mendham, E., J. Millar, and A. Curtis. 2007. Landholder participation in native vegetation management in irrigation areas. 
Ecological Management \& Restoration 8(1):42-48. https://doi. org/10.1111/j.1442-8903.2007.00331.x

Moore, H. E., I. D. Rutherfurd, and M. C. Peel. 2018. Excluding stock from riverbanks for environmental restoration: the influence of social norms, drought, and off-farm income on landholder behaviour. Journal of Rural Studies 62:116-124. https://doi.org/10.1016/j.jrurstud.2018.07.012

Mould, S., and K. Fryirs. 2018. Contextualising the trajectory of geomorphic river recovery with environmental history to support river management. Applied Geography 94:130-146. https://doi. org/10.1016/j.apgeog.2018.03.008

Mould, S. A., K. Fryirs, and R. Howitt. 2018. Practicing sociogeomorphology: relationships and dialogue in river research and management. Society \& Natural Resources 31(1):106-120. https://doi.org/10.1080/08941920.2017.1382627

Pahl-Wostl, C., M. Craps, A. Dewulf, E. Mostert, D. Tabara, and T. Taillieu. 2007. Social learning and water resources management. Ecology and Society 12(2):5. https://doi. org/10.5751/ES-02037-120205

Pahl-Wostl, C., P. Jeffrey, N. Isendahl, and M. Brugnach. 2011. Maturing the new water management paradigm: progressing from aspiration to practice. Water Resources Management 25 (3):837-856. https://doi.org/10.1007/s11269-010-9729-2

Pauly, D. 1995. Anecdotes and the shifting baseline syndrome for fisheries. Trends in Ecology \& Evolution 10(10):430. https://doi. org/10.1016/S0169-5347(00)89171-5

Reed, M. S. 2008. Stakeholder participation for environmental management: a literature review. Biological Conservation 141 (10):2417-2431. https://doi.org/10.1016/j.biocon.2008.07.014

Reed, M. S., A. C. Evely, G. Cundill, I. Fazey, J. Glass, A. Laing, J. Newig, B. Parrish, C. Prell, C. Raymond, and L. C. Stringer. 2010. What is social learning? Ecology and Society 15(4):r1. https://doi.org/10.5751/es-03564-1504r01

Rhoads, B. L., D. Wilson, M. Urban, and E. E. Herricks. 1999. Interaction between scientists and nonscientists in communitybased watershed management: emergence of the concept of stream naturalization. Environmental Management 24:297-308.

Rogers, K. H. 2006. The real river management challenge: integrating scientists, stakeholders and service agencies. River Research and Applications 22(2):269-280. https://doi.org/10.1002/ $\underline{\text { rra. } 910}$

Rustomji, P. 2008. A comparison of Holocene and historical channel change along the Macdonald River, Australia. Geographical Research 46(1):99-110. https://doi.org/10.1111/ j.1745-5871.2007.00495.x

Selinske, M. J., J. Coetzee, K. Purnell, and A. T. Knight. 2015. Understanding the motivations, satisfaction, and retention of landowners in private land conservation programs. Conservation Letters 8(4):282-289. https://doi.org/10.1111/conl.12154

Seymour, E., A. Curtis, D. J. Pannell, A. Roberts, and C. Allan. 2011. Same river, different values and why it matters. Ecological Management \& Restoration 12(3):207-213. https://doi.org/10.1111/ j.1442-8903.2011.00605.x
Sturgis, P., and N. Allum. 2004. Science in society: re-evaluating the deficit model of public attitudes. Public Understanding of Science 13(1):55-74. https://doi.org/10.1177/0963662504042690

Tadaki, M., J. Sinner, and K. M. A. Chan. 2017. Making sense of environmental values: a typology of concepts. Ecology and Society 22(1):7. https://doi.org/10.5751/ES-08999-220107

Turnhout, E., C. Waterton, K. Neves, and M. Buizer. 2013. Rethinking biodiversity: from goods and services to "living with." Conservation Letters 6(3):154-161. https://doi.org/10.1111/ j.1755-263X.2012.00307.X

Urgenson, L. S., H. E. Prozesky, and K. J. Esler. 2013. Stakeholder perceptions of an ecosystem services approach to clearing invasive alien plants on private land. Ecology and Society 18(1):26. https:// doi.org/10.5751/ES-05259-180126

Wenger, E. 2010. Communities of practice and social learning systems: the career of a concept. Pages 178-198 in C. Blackmore, editor. Social learning systems and communities of practice. Springer, London, UK. https://doi.org/10.1007/978-1-84996-133-2_11

West, S., L. J. Haider, V. Masterson, J. P. Enqvist, U. Svedin, and M. Tengö. 2018. Stewardship, care and relational values. Current Opinion in Environmental Sustainability 35:30-38. https://doi. org/10.1016/j.cosust.2018.10.008 
Appendix 1. Interview guides used in this research, for landholders and professional practitioners.

Interview guide: Landholders

1. Background and relationship to place

1.1. How did you come to live in the Macdonald Valley?

1.2. Do you live and work here full-time?

1.3. What was your earliest/first impression of the valley and the river?

1.4. When you picture the valley in your head, what do you see/ what do you think of?

1.5. Is it important to you to be close to the river?

2. Changes in environment and community

2.1. Have you noticed any changes in the valley in your time here? (Prompt: changes in community, changes in physical landscape, e.g. vegetation or river)

2.1.1. How do you feel about those changes?

2.1.2. Do those changes make you feel differently about your environment/community?

2.2. What do you remember about flooding in the valley?

2.2.1. Which floods do you remember?

2.2.2. How have floods impacted your life?

2.2.3. How do you think flooding impacts on the community? (Prompt: day-to-day and longer-term)

2.2.4. Do you worry about flooding?

2.2.5. Has a flood ever made you feel differently about your environment and community? 
3. River health and recovery

3.1. Do you think the river is healthier, less healthy or the same as when you first arrived?

3.2. In your opinion, what might a healthier version of this river look like?

3.3. Have you heard people talking about the river 'recovering'?

3.3.1. What does that word mean to you in the context of this river?

3.3.2. Do you think the river is recovering?

3.3.2.1. How do you see/not see recovery occurring?

3.3.3. How do you feel about seeing / not seeing recovery?

3.4. Have you participated in river rehabilitation activities?

4. Future directions and aspirations

4.1. How do you think the river might look in $5,10,20$ or 100 years?

4.1.1. How do you feel about your prediction - does that sit well with you?

4.2. Do you think there are any challenges in the way of the river becoming healthier?

5. Closing

5.1. Is there anything we haven't covered that you think might be interesting for this research?

5.2. Do you have any questions about this research or how your responses will be handled?

5.3. How would you like to be kept informed about how this research progresses? 
Interview guide: River management practitioners

1. Opening

1.1. How long have you worked in the river management industry?

1.2. How long have you worked with your current institution?

1.3. How would you describe your role in your institution?

2. Institution

2.1. How would you describe your institution's role in river management? [Prompt: responsibilities, key activities? Note: How does participant describe role - e.g. in policy, action or relationally?]

2.2. Which other groups/institutions do you and your organization have contact with in river management?

2.2.1. In what capacity, when and how?

2.3. How would you describe your institution's approach to river management?

2.3.1. What kind of thinking/principles underpin your practice?

2.3.2. What are the priorities and common key goals/KPIs?

2.3.3. Where does your practice get direction from? [Prompt: e.g. policy, higher management?]

2.3.4. Who decides where and what management approaches and activities take place, and how do they make that decision?

3. River recovery

3.1. Are you familiar with the terms, 'river recovery' or 'recovery enhancement'?

3.1.1. What do you understand those terms to mean?

3.1.2. How did you become acquainted with these concepts?

3.1.3. (How) do you apply these concepts in river management?

4. Relationships 
4.1. Are relationships (people-people; people-place) important for you in your management practice?

4.1.1. What kinds of relationships, and how are relationships important?

4.2. What do you do to build and maintain relationships?

4.3. Are you encouraged or supported (by employer/organization) to focus on relationships in your work?

5. Closing

5.1. Do you have any questions about this research or how your responses will be used?

5.2. How would you like to be kept informed about the progress of this research? [E.g. by email/post/phone] 